\title{
POTENSI PENGEMBANGAN MIKRO HIDRO SUNGAI PASAK SULING KABUPATEN GUNUNG MAS KALIMANTAN TENGAH
}

\author{
MICRO HYDRO DEVELOPMENT POTENTIAL OF PASAK SULING RIVER \\ GUNUNG MAS DISTRICT, CENTRAL KALIMANTAN
}

\author{
Apu R. Anggen ${ }^{1}$ \\ ${ }^{1}$ Balai Wilayah Sungai Kalimantan II, Kementerian Pekerjaan Umum dan Perumahan Rakyat \\ Korespondensi: apuanggen@gmail.com
}

\begin{abstract}
ABSTRAK
Masyarakat di Desa Karason Raya Kecamatan Tewah belum memiliki akses pada jaringan listrik negara (PLN), padahal listrik sangat diperlukan bagi pembangunan di desa ini. Desa Karason Raya memiliki potensi sumber daya air yang dapat dimafaatkan sebagai Pembangkit Listrik Tenaga Mikro Hidro, namun sumber daya ini belum termanfaatkan secara optimal. Penelitian ini bertujuan untuk mengetahui kondisi ekonomi sosial, kondisi geologi, hidrologi, besarnya daya yang dapat terbangkitkan oleh PLTMH serta analisis SWOT terhadap aspek-aspek yang mempengaruhi pengembangan PLTMH di Desa Karason Raya. Penelitian ini dilakukan di Desa Karason Raya Kecamatan Tewah. Metodologi yang digunakan adalah observasi lapangan, wawancara dan analisi data sekunder unuk memperoleh data-data yang diperlukan. Hasil penelitian menunjukan bahwa jenis batuan Malihan Pinoh (PzRp) yang terdiri atas filit, skis, kuarsit dan genes. Kondisi kemiringan tanah sepanjang Sungai Pasak Suling anak sungai Bayang cukup terjal di kedua sisi sungai, kemiringan sungai sebesar $0.0009 \mathrm{~m}$. Sedangkan keadaan fisiografi sepanjang sungai merupakan perbukitan batuan yang tidak simetris. Luas Catchment area 7,50 $\mathrm{Km}^{2}$, debit air terukur $1,30 \mathrm{~m}^{3} /$ detik, tinggi jatuh air 13 $\mathrm{m}$ dan potensi daya yang dihasilkan sebesar 165.789 watt.
\end{abstract}

Kata Kunci: Mikrohidro, PLTMH, sungai

\begin{abstract}
Community in Desa Karason Raya District Tewah have no access to the State Electricity Network (PLN), when electricity is needed for development in this village. Karason Raya Village has potential of water resources that can be used as a generator of Micro Hydro Power Plant (MHPP) but these resources are not optimally explored. This study aims to determine the socio-economic conditions, geological conditions, hydrology. The amount of power that can be provided by the Micro Hydro Power Plant (MHPP) and the strategies when the Micro Hydro Power Plant (MHPP) wll be developed by SWOT Analysis. Research is done in Desa Karason Raya District Tewah. Methodology used was secondry data analysis, interviews, and field observations to obtain the necessary data. Results showed that the type of Malihan Pinoh rock (PzRp) composed of fillit, kis, quartize and genealogy. The slope of ground conditions along Sungai Pasak suling tributary quite steep on both the river are rocky hills that are not symmetrical. Calhmet wide area $7.50 \mathrm{Km}^{2}$, $1.30 \mathrm{~m}^{3} / \mathrm{sec}$ measureable water discharge, 13 metres high water fall and potential generated power of $168.339,60$ watts.
\end{abstract}


Keywords: Microhydro, $M H P$, river

\section{PENDAHULUAN}

\section{Latar Belakang}

Kalimantan Tenfah dikaruniai dengan kekayaan sumber daya alam yang melimpah. Sayangnya potensi sumber daya alam selama ini belm dimanfaatkan secara optimal dan bijak. Pemanfaatan sumber daya alam selama ini masih terbatas pada barang-barang tambang dan hasil hutan berupa kayu. Dampak dari pemanfaatan sumber daya alam yang kurang bijak mulai dirasakan oleh masyarakat seperti banjir, keruhnya air sunga, menurunnya potensi hutan sampai dengan hilangnya keanekaragaman hayati.

Besarnya potensi sumber daya alam yang dimiliki Kalimatan Tengah tidak seeta menjamin bahwa masyarakat yang tinggal di wilayah ini hidup dalam kemakmuran. Salah satu kondisi ironis yang dirasakan mayarakat adalah keterbatasan masyarakat terhadap layan listrik.

Ketersediaan energi listrik di pedesaan sebagai salah satu bentuk energi yang siap pakai, selain untuk penerangan tentu saja akan mendorong peningkatan sarana pendidikan, kesehatan dan keamanan lingkungan serta dapat menigkatkan penyediaan lapangan kerja baru.

Umumya daerah pedesaan di Kabupaten Gunung Mas Kalimantan Tengah tersebar di sepanjang daerah aliran sungai. Daerah pedesaan terpencil yang belum terjangkau jaringan listrik nasional (PLN) meupakan suatu masalah bagi pembangunan dan pengembangan masyarakat pedesaan.

Kebutuhan energi masyarakat pedesaan terpencil untuk penerangan, dan kebutuhan lainya umumnya berasal dari minyak, baterai, atau accu yang dalam jangka waktu tertentu harus diisi ulang (recharge).

Salah satu cara menyelesaikan permasalahan ini adalah dengan menggali sumber-sumber potensi energi yang ada disekitar desa, yaitu sumber energi air. Berdasarkan pemikiran diatas maka melalui suatu kajian studi tentang Potensi pengembangan mikro hidro potensi PLTMH ini dapat diharapkan mendapat gambaran tentang kemungkinan dikembangkannya listrik desa di Kabupaten Gunung Mas. Hasil kajian ini diharapkan mampu mengawali perubahan dan perkembangan desa-desa di Kabupaten Gunung Mas terutama dalam hal ketersediaan litrik.

\section{Tujuan Penelitian}

1. Mengetahui kondisi sosial ekonomi masyarakat di desa yang akan di bangun PLTMH

2. Mengetahui kondisi geologi teknik (daya dukung tanah) di lokasi pengembangan PLTMH

3. Mengetahui kondisi hidrologi Sungai Pasak Suling dari anak Sungai Bayang

\section{TINJAUAN PUSTAKA}

Untuk mencari besar debit banjir rencana (design flood) dengan return periode tertentu, biasanya menggunakan data debit sungai atau dengan data curah hujan, yaitu di ambil dari hasil pengamatan pada tahun lalu, makin lama jangka aktu pengamatan dan pengumpulan data maka akan di dapatkan hasil yang baik. (Dinas PU, 2008). Beberapa analisis data yang digunakan adalah :

1) Perhitungan Debit Air

$$
\begin{aligned}
& \mathbf{Q}=\mathbf{V} \mathbf{x} \mathbf{A} \\
& \text { Dimana : } \\
& \mathrm{Q}=\text { debit }\left(\mathrm{m}^{3} / \text { detik }\right) \\
& \mathrm{A}=\text { luas permukaan dan parit }\left(\mathrm{m}^{2}\right) \\
& \mathrm{V}=\text { kecepatan air }(\mathrm{m} / \text { detik })
\end{aligned}
$$

2) Analisa Hidrologi.

A. Perhitungan Curah Hujan

$$
R T \frac{R A}{1}
$$

Dimana :

$\mathrm{RT}=$ curah hujan rata-rata pada wilayah A

$\mathrm{RA}=$ jumlah curah hujan pada wilayah $\mathrm{A}$ hujan

$$
1 \text { = satu titik stasion pengamatan curah }
$$

a. Metode Gumbel

$$
\begin{aligned}
& \text { RT = Xa + (YT-YN) } / \text { SN x SX } \\
& \text { Dimana : } \\
& \text { RT = curah hujan rata-rata } \\
& \text { Xa = curah hujan rata-rata tahunan }
\end{aligned}
$$


$\mathrm{YT}=$ nilai reduced variate

$\mathrm{SN}=$ nilai reduced standard deviation

$\mathrm{SX}=$ standar deviasi

$\mathrm{YN}=$ nilai reduced mean

b. Metode Weduwen

$$
\boldsymbol{R}_{\max }=\boldsymbol{M P} \times \boldsymbol{R 7 0}
$$

\section{$R 70=R \max /_{M P}$}

Dimana :

$\mathrm{Mp}=$ koefesien (untuk suatu return period tertentu)

$\mathrm{R} 70=$ curah hujan dengan return period 70 th

Rmax $=$ curah hujan max. selama pengamatan $\mathrm{N}$ tahun

\section{METODE}

\section{Lokasi Penelitian}

Penelitian ini dilaksanakan di Desa Karason Raya, Kecamatan Tewah Kabupaten Gunung Mas, Provinsi Kalimatan Tengah. Penelitian ini dilaksanakan selama 3 bulan (Agustus - September - Oktober 2010).

Bahan yang digunakan dalam penelitian ini antara lain : peta lokasi. Peta topografi, data hidrologi dan peta geologi. Sedangkan peralatan yang digunakan antara lain : GPS (global position system), water pass, meteran, theodolit,computer dan peralatan lapangan.

\section{Desain Penelitian}

Data yang digunakan dalam penelitian ini berupa sekunder dan primer yang diperoleh dalam observasi lapngan. Data primer yang digunakan dalam penelitian ini adalah :

1. Data debit air sungai, diukur dengan menggunakaan current meter dan floating

2. Data besarnya Head

3. Data kecepatan air, diukur dengan menggunakan alat ukur current meter

4. Masukan dari berbagai pihak, dilakukan dengan metode wawancara

Sedangkan data sekunder yang digunakan adalah :

1. Peta topografi

2. Curah hujan selama 10 tahun terakhir di ambil dari stasiun pengamatan curah hujan Kabupaten Gunung Mas

Pengolahan dan analisis data berupa :

a. Analisa data topografi untuk mengetahui

head (tinggi terjun) dan luas tangkapan DAS

b. Analisa hidrolgi dan hidroulika berupa perhitungan curah hujan, debit dan kecepatan aliran sungai

Rincian tahapan kegiatan penelitian ini adalah sebagai berikut :

1. Persiapan

2. Analisis data sekunder

3. Observasi lapangan

4. Analisis data

Variabel Penelitian

1. Curah hujan, yaitu besarnya curah hujan harian maksimum tahunan selama sepuluh tahun terakhir

2. Debit air sungai, meliputi debit andalan ( serial data debit ) serta debit rencana

\section{HASIL DAN PEMBAHASAN}

\section{Gambaran Umum Lokasi Penelitian}

Desa Karason Raya berbatasan dengan :

- Sebelah Barat : Desa Haruwu

- Sebelah Selatan : Desa Tajau Urap

- Sebelah Timur : Desa Batu Karung

- Sebelah Utara : Desa Habaun

Desa Karason Raya saat ini belum terjangkau oleh listrik dari Perusahaan Listrik Negara (PLN). Kebutuhan energi untuk penerangan rumah saat ini menggunakan petromak, lampu tempel, PLTS (Pembangkit Listrik Tenaga Surya) dan sebagian menggunakan genset

\section{Kondisi Topografi}

Air yang akan digunakan rencana untuk PLTMH Karason berasal dari Sungai Pasak Suling dari anak Sungai Bayang. Kondisi kemiringan tanah sepanjang Sungai Pasak Suling cukup terjal di kedua sisi sungai. Sedangkan keadaan fisiografi sepanjang sungai merupakan perbukitan bukan batuan yang tidak simetris.

\section{Analisa Hidrologi}

Data hidrologi digunakan untuk penempatan dan perencanaan pintu intake dan rumah turbin, dimana nantinya di analisa untuk mengetahui besar debit banjar rencana ( design period ), artinya pada periode tertentu banjur tersebut akan terjadi lagi, misalnya banjir 50 thaunan adalah banjir akan terjadi 50 tahun sekali. Kegiatan survey hidrologi dan hidrogeometri dilaksanakan untuk mendapatkan data besarnya curah hujan dan debit 
aliran sungai. Dalam penelitian ini penulis menggunakan data curah hujan yang di ambil dai stasiun yang berdekatan dengan lokasi penelitian, yaitu pada stasiun Kuala Kurun, dengn lama waktu pengamatan 10 tahun. Data curah hujan terbesar tahunan pada suatu daerah pengairan Kuala Kurun.

\section{Curah hujan rata-rata harian maksimum per tahun dan curah hujan maksimum tahunan.}

Metode yang digunakan dalam perhitungan adalah : metode gumbel dan metode weduwen. Untuk mendapatkan hasil curah hujan rata-rata ( RT ) maka dalam perhitungan digunakan metode Arimatik.

\section{a. Curah hujan rata-rata}

Curah hujan rata-rata (RT) dihitung dari jumlah besarnya curah hujan dalam waktu tertentu (bulan/tahun) dibagi dengan besaran waktu (bulan/tahun)

\section{b. Catchment area}

Pengukuran luas catchment area dilakukan dengan menghitung luas daerah yang dibatasi ( dikelilingi oleh daerah tertinggi/ pegunungan dimana keseluruhan air di daerah tersebut mengalir ke daerah yang akan di ukur.

Tabel 1. Hasil pengukuran panjang dan lebar catchment area (m)

\begin{tabular}{ccc}
\hline No & Titik & $\begin{array}{c}\text { Panjang/ lebar Catchment area } \\
(\mathrm{m})\end{array}$ \\
\hline 1 & I & 2975 \\
2 & II & 4675 \\
3 & III & 4250 \\
4 & IV & 2140 \\
\hline
\end{tabular}

\section{c. Data curah hujan}

Untuk mendapatkan gambaran mengenai penyebaran hujan di seluruh daerah, di beberapa tempat tersebar pada DAS dipasang alat penakar hujan.

\section{d. Perhitungan curah hujan dengan}

\section{Metode Arimatik}

Curah hujan wilayah atau curah hujan daerah yang dinyatakan dalam satuan milimeter. Hasil perhitungan curah hujan arimetik dapat dilihat pada Tabel 2.
Tabel 2. Data curah hujan rata-rata maksimum tahunan degan metode arimatik

\begin{tabular}{ccc}
\hline Tahun & $\begin{array}{c}\text { Curah hujan } \\
\text { max tahunan }\end{array}$ & $\begin{array}{c}\text { Perhitungan curah } \\
\text { hujan rata-rata dengan } \\
\text { metode arimatik (RT) }\end{array}$ \\
\hline 2000 & 129,8 & 129,8 \\
2001 & 139,8 & 139,8 \\
2002 & 120,5 & 120,5 \\
2003 & 170,2 & 170,2 \\
2004 & 133,6 & 133,6 \\
2005 & 136,2 & 136,2 \\
2006 & 128,9 & 128,9 \\
2007 & 145,8 & 145,8 \\
2008 & 133 & 133 \\
2009 & 128,2 & 128,2 \\
\hline
\end{tabular}

Sumber : Dinas PU. Provinsi Kalimantan Tengah

\section{e. Perhitungan curah hujan dengan Metode Gumbel}

Kedua metode ini digunakan untuk menghitung curah hujan maksimum tahunan untuk kala ulang 10 sampai dengan 100 tahun yaitu $R \max _{10}$, $\operatorname{Rmax}_{50}, \operatorname{Rmax}_{100}$. ( I Made. K 2010 )

Tabel 3. Analisa hidrologi dengan Metode Gumbel

\begin{tabular}{|c|c|c|c|}
\hline Tahun & $\mathrm{Xi}(\mathrm{mm})$ & (Xi-Xa) & $(\mathrm{Xi}-\mathrm{Xa}) 2$ \\
\hline 2000 & 129,8 & $-6,58$ & 43,3 \\
\hline 2001 & 139,8 & 3,42 & 11,7 \\
\hline 2002 & 120,5 & $-15,88$ & 252,17 \\
\hline 2003 & 170,2 & 33,82 & 1143,79 \\
\hline 2004 & 133,6 & $-2,78$ & 7,73 \\
\hline 2005 & 136,2 & $-0,18$ & 0,03 \\
\hline 2006 & 128,9 & $-7,48$ & 55,95 \\
\hline 2007 & 145,8 & 9,22 & 85,01 \\
\hline 2008 & 133 & $-3,38$ & 11,42 \\
\hline \multirow[t]{4}{*}{2009} & 128,2 & $-10,18$ & 103,63 \\
\hline & $\sum \mathrm{Xi}$ & $1.363,80$ & \\
\hline & $\mathrm{Xa}$ & 136,4 & \\
\hline & $\sum(\mathrm{Xi}-\mathrm{Xa})^{2}$ & & $1.714,74$ \\
\hline
\end{tabular}

Tabel 4. Hasil perhitungan metode gumbel

\begin{tabular}{ccc}
\hline $\mathrm{T}$ & YT & $\mathrm{Rmax}(\mathrm{mm})$ \\
\hline 10 & 2,25 & 184,94 \\
25 & 3,198 & 211,17 \\
50 & 3,902 & 230,65 \\
100 & 4,6 & 249,97 \\
\hline
\end{tabular}




\section{f. Perhitungan curah hujan dengan Metode Weduwen}

R Max dalam 50 tahun untuk daerah stasiun sungai pasak suling dengan metode weduwen (I Made.K 2010).

Tabel 5. Hasil perhitungan metode weduwen

\begin{tabular}{ccc}
\hline $\mathrm{T}$ & $\mathrm{MN}$ & $\mathrm{Rmax}(\mathrm{mm})$ \\
\hline 10 & 0.603 & 145.33 \\
25 & 0.845 & 204.06 \\
50 & 0.948 & 228.87 \\
100 & 1.050 & 253.49 \\
\hline
\end{tabular}

\section{g. Perbandingan nilai perhitungan Weduwen dan Gumbel}

Untuk mendapatkan nlai akhir curah hujan maksiumum yang dipergunakan sebagai bahan perhitungan maka hasil perhitungan metode weduwen dan hasil perhitungan metode gumbel di rata-ratakan.

Tabel 6. Rata-rata hasil perhitungan Weduwen dan Gumbel

\begin{tabular}{llllll}
\hline \multirow{2}{*}{$\mathrm{T}$} & \multirow{2}{*}{ YT } & \multirow{2}{*}{ MN } & \multicolumn{2}{l}{ Rmax (mm) } & Rata- \\
\cline { 4 - 5 } & & & Gumbel & Weduwen & rata \\
\hline 10 & 2,25 & 0.603 & 184,4 & 145,33 & 165,14 \\
25 & 3,198 & 0.845 & 211,17 & 204,06 & 207,59 \\
50 & 3,902 & 0.948 & 230,65 & 228,87 & 229,76 \\
100 & 4,600 & 1.050 & 249,97 & 253,49 & 251,73 \\
\hline
\end{tabular}

\section{Debit Banjir Rencana}

Analisa hidrologi juga dilakukan untuk mengetahui besarnya debit banjir rencana. Debit banjir rencana adalah debit air dengan metode periode ulang tertentu yang diperkirakan akan elalui suatu fungsi ungai atau bangunan air. Perhitungan debit air rencana ini penting agar kita dapat memperkirakan kekuatan dan ukuran bangunan air yang sesuai yang dapat mengatasi kemungkinan debit terbesar sekalipun. Debit banjir rencana dihitung dengan Metode Weduwen dengan rumus sebagai berikut ( I Made.K 2010 ).

$$
\begin{aligned}
& \text { QT } \quad \text { a } \cdot \beta \cdot \mathrm{q} \frac{R t}{240} \cdot F \\
& \mathrm{a}=1-\frac{4,1}{q+7} \\
& \beta=\frac{\frac{120+t+1}{\frac{t+F}{120+F}} x F}{\frac{120+2,3+1}{\frac{2,8+7,5}{120+7,5}} x 7,50} \\
& \beta=\mathbf{0 , 9 4 4} \\
& \mathrm{q}=\frac{67,5}{t+1,45}
\end{aligned}
$$

$$
\begin{aligned}
& \mathrm{q}=\frac{67,5}{2,30+1,45}=\mathbf{1 7 , 9 8 7} \\
& \mathrm{a}=1-\frac{4,1}{17,987+7} \\
& \mathrm{t}=\frac{0,476 \times F^{0,875}}{(a x \beta \times q) 0,125 \times S 0,25} \\
& \mathrm{t}=\frac{0,476 \times 7,50^{0,875}}{(0,836 \times 0,943 \times 17,987) 0,125 \times 0,009.0,25}=\mathbf{2 , 3 6}
\end{aligned}
$$

Dimana :

$\mathrm{QT}=$ debit dengan periode ulang $\mathrm{T}$ tahun ( $\mathrm{m}^{3} /$ detik)

$\mathrm{a}=$ koefesien pengaliran

$\beta=$ faktor reduksi

$\mathrm{q}=$ debit persatuan luas $\left(\mathrm{m}^{3} /\right.$ detik $\left./ \mathrm{km}\right)$

$\mathrm{RT}=$ curah hujan max selama 24 jam, untuk periode ulang $\mathrm{T}$ tahun $(\mathrm{mm})$

$\mathrm{F}=$ luas catchment area

$\mathrm{S}=$ kemiringan sungai

Maka nilai $\mathrm{t}$ dari cara coba-coba di dapat $\mathrm{t}=2,36$. Hasil pehitungan debit banjir rencana Sungai Pasak Suling dengan menggunakan metode Weduwen dapat dilihat pada tabel 7 .

Tabel 7. Debit banjir rencana metode Weduwen

\begin{tabular}{ccc}
\hline $\begin{array}{c}\text { Periode Ulang } \\
\text { (tahun) }\end{array}$ & RT (mm) & QT (m3/det) \\
\hline 10 & 165,14 & 73,2 \\
25 & 207,59 & 92,08 \\
50 & 229,78 & 101,91 \\
100 & 251,73 & 111,66 \\
\hline
\end{tabular}

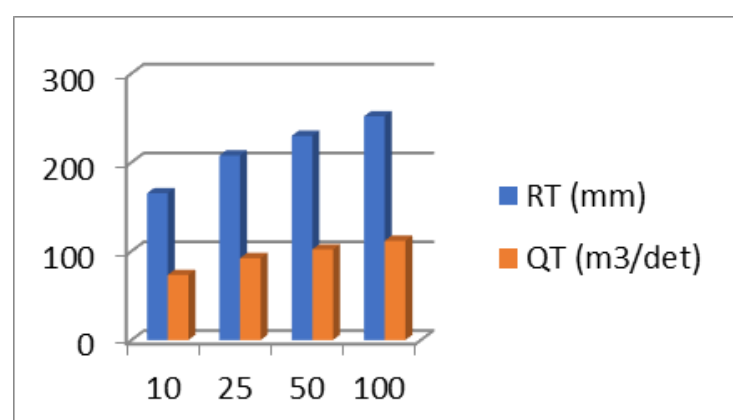

Gambar 1. Debit banjir rencana metode Weduwen

Dari tabel di atas kita dapat melihat bahwa dalam periode ulang 10 tahun debit rencana sebesar 73,25 $\mathrm{m}^{3} /$ det. Hal ini juga berarti bahwa dalam kurun waktu sepuluh tahun kemungkinan terjadi debit banjir rencana sebesar $73,25 \mathrm{~m}^{3} /$ det. Dalam perhitungan untuk membangun bangunan air biasanya digunakan periode ulang 50 tahun. Dari 
tabel di atas terlihat bahwa besarnya debit pada periode ulang 50 tahun adalah 101,91 m3/det. Berati dalam kurun waktu 50 tahun terjadi peluang satu kali debit sungai Pasak Suling mencapai $101,91 \mathrm{~m}^{3} /$ detik.

Pintu intake akan ditempatkan di Sungai Pasak Suling dan bangunan rumah turbin di bangun disekitar air yang jatuh ( air terjun) dengan memperlihatkan elevasi air maksimum, untuk keperluan tersebut maka perlu diketahui dimensi sungai pasak suling dengan debit $101,91 \mathrm{~m}^{3} /$ det.

Untuk menghitung dimensi sungai pasak suling perlu diketahui data sepeti dibawah ini.

- Lebar sungai rata-rata

- Kemiringan sungai

- Debit(Qso) banjir rencana

- Koefisien kekasaran dinding

Untuk menghitung tinggi air (h) Sungai Pasak Suling dihitung berdasarkan debit banjir rencana Qso=101,91 m³/det yaitu:

Dimana:

$\mathrm{V}=(\mathrm{I} / \mathrm{N}) \times \mathrm{R}$ i

$\mathrm{K}=50$

$\mathrm{i}=0,009$

$\mathrm{A}=\mathrm{b}+2 \mathrm{~h} \sqrt{m^{2}}+2^{2}$

$\mathrm{R}=\mathrm{A} / \mathrm{P}$

Selanjutnya digunakan metode coba-coba untuk mengetahui tinggi air di sungai (H) yang mendekati nilai debit Q50. Maka di dapat nilai $\mathrm{H}=$ 3,38 m dengan perhitungan sebagai berikut :

$\mathrm{A}=3,5+(3,5+(4 \mathrm{X} 3,38) \mathrm{X}(3,382) / 2=34,68 \mathrm{M}$

$\mathrm{P}=3,5+2.3,38 \sqrt{(1+2)^{2}}=22,56 \mathrm{M}$

$\mathrm{R}=134,68 / 22,56=1,54 \mathrm{M}$

$\mathrm{V}=1 /(0,05 \times 1,54 \mathrm{X} 0,009)=2,92 \mathrm{~m} / \mathrm{det}$

$\mathrm{Q} 50=34,68 \times 2,92=101,13 \mathrm{~m}^{3} / \mathrm{det}$

Tabel 8. Hasil perhitungan Sungai Pasak Suling

\begin{tabular}{|c|c|c|c|c|c|}
\hline \multirow{2}{*}{$\mathrm{NO}$} & B & \multirow{2}{*}{$\begin{array}{l}\mathrm{H} \\
\mathrm{m}\end{array}$} & \multicolumn{2}{|c|}{ A } & $\mathrm{P}$ \\
\hline & M & & \multicolumn{2}{|c|}{$\mathrm{m}$} & $\mathrm{m}$ \\
\hline 1 & 3,5 & 3,38 & \multicolumn{2}{|c|}{34,68} & 22,56 \\
\hline $\mathrm{NO}$ & $\begin{array}{l}\mathrm{R} \\
\mathrm{m}\end{array}$ & $\mathrm{i}$ & $\begin{array}{c}\mathrm{V} \\
\mathrm{m} / \mathrm{det}\end{array}$ & $\begin{array}{c}\mathrm{Q} \\
\mathrm{m}^{3} / \mathrm{det}\end{array}$ & $\begin{array}{c}\text { Qth } \\
\mathrm{m}^{3} / \mathrm{det}\end{array}$ \\
\hline 1 & 1,54 & 0,009 & 2,92 & 101,13 & $\begin{array}{c}\mathrm{Q} 50= \\
101,91 \\
\mathrm{~m} / \mathrm{det}\end{array}$ \\
\hline
\end{tabular}

Dari hasil perhitungan di atas pada tabel 8 dengan tinggi air $(\mathrm{H})$ sebesar 3,38 $\mathrm{m}$ dan $\mathrm{Q}$ sebesar 101,13 maka tinggi air $(\mathrm{H})$ memenuhi syarat

Dimana:

$\mathrm{H}=$ tinggi air normal

$\mathrm{A}=$ luas penampang basah

$\mathrm{P}=$ keliling areal basah

$\mathrm{R}=$ jari-jari penampang basah

$\mathrm{i},=$ kemiringan dasar sungai

$\mathrm{V}=$ kecepatan air

$\mathrm{Q}=$ debit air

$\mathrm{B}=$ lebar bawah

Gambar penampang sungai secara umum dapat dilihat pada gambar 2

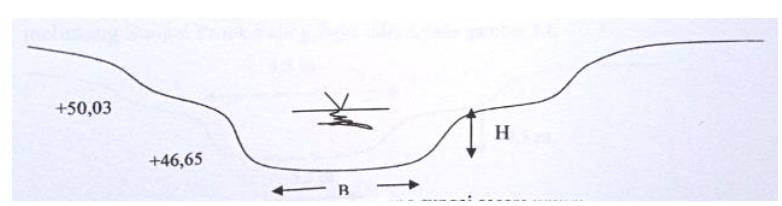

Gambar 2. Penampang melintang Sungai Pasak Suling

\section{Perhitungan luas penampang Sungai Pasak Suling}

Perhitungan luas penampang sungai diawali dengan mengetahui dimensi sungai. Perhitungan dimensi sungai dilakukan dengan melakukan pengukuran 5 titik dengan 2 kali pengkuran yaitu lebar dasar sungai (B), dan tinggi muka air (H).

Dari hasil pengukuran pertama (I), kedua (II) di lapangan dan studi geotografi tepian sungai maka diketahui dimensi penampang melintang Sungai Pasak Suling yang dapat dilihat pada tabel 8 dan tabel 9.

Tabel 9. Penampang Sungai Pasak Suling pengukuran (I)

\begin{tabular}{cccc}
$\begin{array}{c}\text { Titik } \\
\text { Pengukuran }\end{array}$ & $\begin{array}{c}\text { Lebar } \\
\text { Bawah } \\
(\mathrm{m})\end{array}$ & $\begin{array}{c}\text { Lebar } \\
\text { Atas }(\mathrm{m})\end{array}$ & $\begin{array}{c}\text { Tinggi } \\
\text { Air }(\mathrm{m})\end{array}$ \\
\hline I & 2,7 & 2,5 & 0,5 \\
II & 3,8 & 5 & 0,3 \\
III & 26 & 5 & 0,5 \\
IV & 4,3 & 6,0 & 0,20 \\
V & 4,1 & 5,5 & 0,20 \\
\hline Jumlah & 17,5 & 24 & 1,7 \\
Rata-rata & 3,5 & 4,8 & $0,34=0,3$ \\
\hline
\end{tabular}

Dari hasil pengukuran titik ke I pada tabel 9 maka dimensi penumpang melintang Sungai Pasak Suling dapat dilihat pada gambar 3 . 


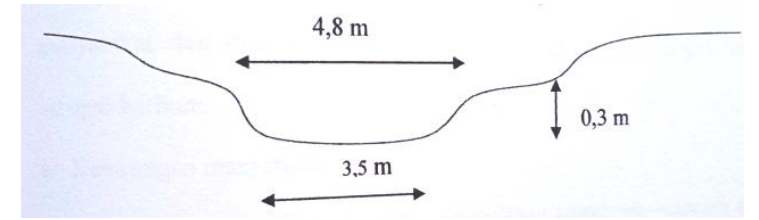

Gambar 3. Penampang melintang Sungai Pasak Suling

Tabel 10 Penampang Sungai Pasak Suling pengukuran (II)

\begin{tabular}{cccc}
$\begin{array}{c}\text { Titik } \\
\text { Pengukuran }\end{array}$ & $\begin{array}{c}\text { Lebar } \\
\text { Bawah }(\mathrm{m})\end{array}$ & $\begin{array}{c}\text { Lebar } \\
\text { Atas }(\mathrm{m})\end{array}$ & $\begin{array}{c}\text { Tinggi } \\
\text { Air }(\mathrm{m})\end{array}$ \\
\hline I & 2,7 & 4,5 & 0,55 \\
II & 3,8 & 5 & 0,40 \\
III & 26 & 5 & 0,56 \\
IV & 4,3 & 6,5 & 0,30 \\
V & 4,1 & 6,0 & 0,30 \\
\hline Jumlah & 17,5 & 27 & 2,11 \\
Rata-rata & 3,5 & 5,4 & 0,422 \\
\hline
\end{tabular}

Dari hasil pengukuran ke II pada tabel 10 di maka dmensi penampang melintang Sungai Pasak Suling dapat dilihat pada gambar 4 .

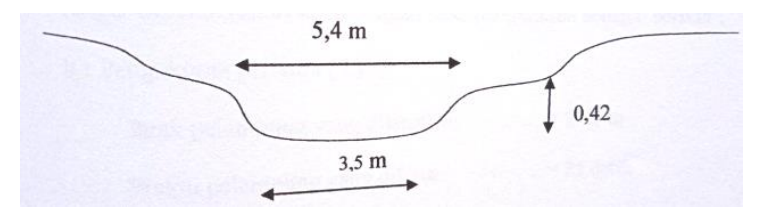

Gambar 4. Penampang melintang Sungai Pasak Suling

\section{PENUTUP}

\section{Kesimpulan}

1. Kondisi sosial ekonomi masyarakat Desa Karason Raya yang terkait dengan rencana pengembangan pembangkit listrik tenaga mikro hidro (PLTMH) adalah :

a. Untuk memenuhi kebetuhan akan energi penerangan, masyarakat Desa Karson Raya masih menggunakan generator panel surya dan lampu minyak tanah

b. Untuk memenuhi kebutuhan akan energi listrik di Desa Karason Raya yang berjumlah 89 kk diperlukan paling sedikit 8.900 watt

2. Kondisi geoogi di Desa Karason Raya juga terdiri dari endapan aluvium, dimana mempunyai sebaran yang luas dan batuan terdiri atas pasir, kerikil dan batu pasir yang dapat menyimpan air.

3. Kondisi hidrologi di Sungai Pasak Suling mampu melaksanakan dengan besar debit minimum 1,32 $\mathrm{m}^{3} /$ detik untuk memenuhi kebutuhan akan energi listrik di Desa Karason Raya juga berjumlah 89 kk diperlukan Pling sedikit 8.900 watt.

4. Potensi daya pembangkit listrik tenaga mikro hidro (PLTMH) yang dapat disalurkan di Desa Karason Raya dengan memanfaatkan potensi sungai Pasak Suling dengan debit minimum $1,32 \mathrm{~m}^{3} /$ detik dan daya terbangkit sebesar $168.339,60$ watt, dimungkinkan untuk dikembangkan dengan pertimbangan debit rencana untuk periode ulang 5o tahun sebesar $101,91 \mathrm{~m}^{3}$ detik

5. Untuk pengembangan PLTMH di Desa Karason Raya, diperlukan langkah-langkah strategis sebagai berikut :

a. Konservasi daerah hulu sungai dan daerah aliran sungai untuk menjaga stabilitas debit air serta fungsi hidrologis kawasan

b. Pelatihan pengembangan kapasitas kelembagaan masyarakat agar mampu mengelola PLTMH

c. Peningkatan pengetahuan dan keterampilan masyarakat dalam mengelola PLTMH

d. Kaloborasi/ kerjasama antara pemerintah, NGO dan perusahaan untuk mengembangkan PLTMH

e. Penetapan peraturan baik oleh pemerintah maupun desa untuk menghindari konversi hutan di sekitar desa dan di daerah hulu sungai

f. Pengelolaan PLTMH yang transparan, terbuka dan partisipatif untuk menghindari konflik sosial

g. Peningkatan kesadaran semua pihak (public awareness) tentang konservasi sumber daya alam.

\section{Saran}

Berdasarkan hasil studi potensi pengembangan PLTMH di Desa Karason Raya dan kondisi topohidrografi Sungai Pasak Suling dengan debit Q $=1,32 \mathrm{~m}^{3} /$ detik, disarankan untuk mengembangkan PLTMH dengan model pembuatan pintu intake dan rumah turbin dengan menggunakan turbin untuk menggerakan generator. Jenis turbin yang sebaiknya digunakan adalah jenis crossflow dengan diamter $225 \mathrm{~mm}$, lebar $400 \mathrm{~mm}$, kecepatan poros 609 RPM daya poros $22 \mathrm{kw}$ untuk ditranmisikan ke generator yang direncanakan dapat mengeluarkan output $20 \mathrm{kw}$ serta efisiensi 
$74 \%$ dengan spesifikasi turbin seperti tersebut diatas maka diameter pipa pesat dai pintu intake sampai rumah turbin sepanjang $\pm 100 \mathrm{~m}$. Besar rumah turbin dengan ukuran panjang $3 \mathrm{~m}$ dan lebar $3 \mathrm{~m}$

\section{DAFTAR PUSTAKA}

Bachtiar \& Neris, Asep. (2008). Pemilihan penggerak mula turbin air untuk sistem pembangkit listrik tenaga mikrohidro (PLTM). Jurnal Ekotrans. ISSN 1411-4615. volume 8 nomor 2, Juli 2008.

Direktorat Jenderal Pengairan. (1980). Cara Menghitung Design Flood. Badan Penerbit Pekerjaan Umum, Jakarta

Enoh, R.Moh. (1993). Suatu eksperimen pembuatan pembangkit lisrik tenaga mikrohidro (PLTM) dengan penggerak mula turbin tanki untuk kelistrikan desa di Kecamatan Lembang Jaya Kabupaten Solok Sumatera Barat. Laporan Penelitian Institut Keguruan dan Ilmu Pendidikan (IKIP) Padang, Padang.

Harto, Sri. (1993). Analisis Hidrologi. Gramedia Pustaka Utama. Jakarta

Kamiana, I Made. (2011). Teknik Perhitungan Debit Rencana Bangunan Air. Graha Ilmu. Yogyakarta

Kodoatie, Robert J., \& Sjarif, Roestam, (2008). Pengelolaan Sumber Daya Air Terpadu (Edisi Revisi). Andi Offset. Yogyakarta

Mulyanto, H. R. (2007). Sungai: Fungsi dan Sifat-sifatnya. Edisi Pertama. Graha Ilmu. Yogyakarta.

Satriyo, Puguh Adi. (2007). Pemanfaatan Pembangkit Listrik Tenaga Mikro Hidro untuk Daerah Terpencil. Puslitbang Iptekhan. Dephan. Jakarta. 